\title{
A new species of the genus Dorytomus Germar, 1817 (Coleoptera: Curculionidae) from Baltic amber
}

\author{
Andris Bukejs \& Andrei A. Legalov*
}

Bukejs, A. \& Legalov, A. A. 2019: A new species of the genus Dorytomus Germar, 1817 (Coleoptera: Curculionidae) from Baltic amber. — Entomol. Fennica 30: 173-178. doi: https://doi.org/10.33338/ef.87174

A new species, Dorytomus groehni Bukejs \& Legalov sp. n. is described and illustrated from Eocene Baltic amber. The new species differs from D. nudus Legalov, 2016 primarily in longer and wider body size, narrower and longer rostrum, slightly convex interstriae distinctly wider than elytral striae and finely punctate pronotum with semierect setae.

A. Bukejs, Institute of Life Sciences and Technologies, Daugavpils University, Vienības 13, Daugavpils,LV-5401,Latvia; E-mail: carabidae@inbox.lv

A. A. Legalov, Institute of Systematics and Ecology of Animals, Siberian Branch, Russian Academy of Sciences, Frunze Street, 11, Novosibirsk 630091, Russia and Tomsk State University, Lenina Prospekt 36, Tomsk 634050, Russia; *Corresponding author's e-mail: fossilweevils@gmail.com

Received 17 March 2019, accepted 23 April 2019

\section{Introduction}

Weevil beetles belong to several families of Curculionoidea, which are well represented in ambers (Legalov 2015). The first weevils from Baltic amber were described in the nineteenth century (Motschulsky 1857, Förster 1891). Thirty-seven species from 27 genera are known from this Lagerstätte (Motschulsky 1857, Förster 1891, Hustache 1942, Ulke 1947, Voss 1953, 1972, Zherikhin, 1971, Wanat \& Borowiec 1986, Kuska 1992, 1996, Rheinheimer 2007, Yunakov \& Kirejtshuk 2011, Legalov 2012, 2013, 2015, 2016a, b, Legalov \& Bukejs 2015, 2018a, b). All these species are extinct and $74 \%$ genera are extinct also. It is possible to find rare new species in new samples that allow to clarify the structure of amber fauna and contribute to the investigation of the weevils' phylogeny.

In the present paper, a new fossil species of the Recent genus Dorytomus Germar, 1817 from the Baltic amber is described.

\section{Materials and methods}

The Baltic amber mines are located along the Baltic Sea coast at the Amber quarry of Yantarny near Kaliningrad in the Kaliningrad Oblast, Russia. The amber of this deposit was probably produced by the pine tree, Pinus succinifera (Pinaceae) (Schubert 1961) or Sciadopitys sp. (Sciadopityaceae) (Sadowski et al. 2016).

The material examined comes from the collection of Dr. Carsten Gröhn (Glinde, Germany) and is deposited in the Center of Natural History (CeNak) (formerly Geological-Paleontological Institute and Museum, GPIH) of the University of Hamburg, Germany. The amber piece was handpolished allowing improved views of the in- 
cluded specimen, and was not subjected to any additional fixation.

The material was studied using a Nikon SMZ® ${ }^{\circledR} 45$ T stereomicroscope. The photographs were taken using a Canon $70 \mathrm{D}^{\circledR}$ camera with a macro lens (Canon MPE-65 mm). Extended depth of field was achieved at high magnifications by combining multiple images from a range of focal planes using Helicon Focus ${ }^{\circledR}$ v. 6.0.18 software. The measurements were taken using an ocular micrometer (expressed in millimetres).

\section{Systematic part}

Family Curculionidae Latreille, 1802

Subfamily Curculioninae Latreille, 1802

Tribe Ellescini C.G. Thomson, 1859

Subtribe Dorytomina Bedel, 1886

Genus Dorytomus Germar, 1817

\section{Dorytomus groehni sp. n. (Figs. 1-2)}

Type material. Holotype: Adult "GPIH 8608, coll. Gröhn", deposited at the Center of Natural History (CeNak) (formerly Geological-Paleontological Institute and Museum, GPIH) of the University of Hamburg, Germany. A complete beetle included in transparent yellow piece of amber with dimensions $26 \times 8 \times 5 \mathrm{~mm}$. The right lateral side of the specimen is almost completely obscured by "milky cover". Syninclusions: an appendage of unknown Insecta, stellate Fagaceae trichomes, few pieces of organic material and gas vesicles.

Type strata. Baltic amber, Upper Eocene.

Type locality. Baltic Sea coast, Yantarny settlement (formerly Palmnicken), Kaliningrad region, Russia.

Diagnosis. The new fossil species is similar to D. nudus Legalov, 2016 from Baltic amber, because the elytra are covered with recumbent setae but differs in narrower and longer rostrum, wide body, slightly convex interstriae distinctly wider than elytral striae, finely punctate pronotum with semierect setae and large body size. It is distinguishable from D. electrinus Legalov, 2016 from Baltic amber by the body having pubescence, the pronotum having larger punctures and the body being larger.
Description. Body. Elongate-oval, slightly convex; unicolorous dark brown (as preserved). Pubescence: dorsum covered with short, very sparse, erect to semierect scale-like setae; elytra additionally with sparse, fine, recumbent pubescence; rostrum with few short, erect scale-like setae dorsally, more robust at base; venter with very sparse and fine semierect setae (distinctly visible on abdomen and head).

Head. Short, evenly covered with dense, deep, small (about as large as eye facet) punctation dorsally, distance between punctures distinctly shorter than diameter of one puncture; with sparse, fine punctation and strong microreticulation ventrally and laterally; vertex convex. Rostrum long, about $1.7 \times$ as long as pronotum, moderately curved downward, thicker than protibiae; antennal scrobes lateral, oblique and directed towards hind margin of eye; covered with sparse, fine punctation. Compound eyes moderately large, oval, vertical diameter $2.1 \times$ as long as transverse diameter, slightly convex, not protruding beyond head outline, with distinct facets. Temples large, about as long as transverse diameter of one eye. Antennae with 11 antennomeres, clavate, with 3-segmented club; sparsely covered with short, semierect setae; apparently inserted in apical one-third of rostrum; moderately long, reaching almost elytral base; scape elongate, almost reaching anterior margin of eye, slightly dilated at apex; funicle with seven antennomeres, slender, antennomere 2 elongate, subcylindrical, nearly as wide as scape apically and about $1.9 \times$ as wide as antennomere 3 , antennomeres 3-8 elongate, slightly dilated apically; antennal club rather wide and long; relative length ratios of antennomeres $2-8$ equal to 13-77-5-5-5-8.

Pronotum. Transverse, narrower than anterior elytral margin, with weak constriction at anterior margin, widest apparently in basal one-third, slightly narrowed anteriad; disc almost flat; densely covered with large and deep punctation, distance between punctures distinctly shorter than diameter of one puncture, interspaces convex (especially at lateral sides) and with microsculpture. Lateral margins widely rounded; anterior margin straight; posterior margin rounded. Prohypomera convex, with dense and large punctation, distance between punctures shorter 
Fig. 1. Dorytomus groehni sp. n., habitus of holotype. - a. Lateral view. - b. Ventro-lateral view. - c. Ventral view. Scale bars $1 \mathrm{~mm}$.

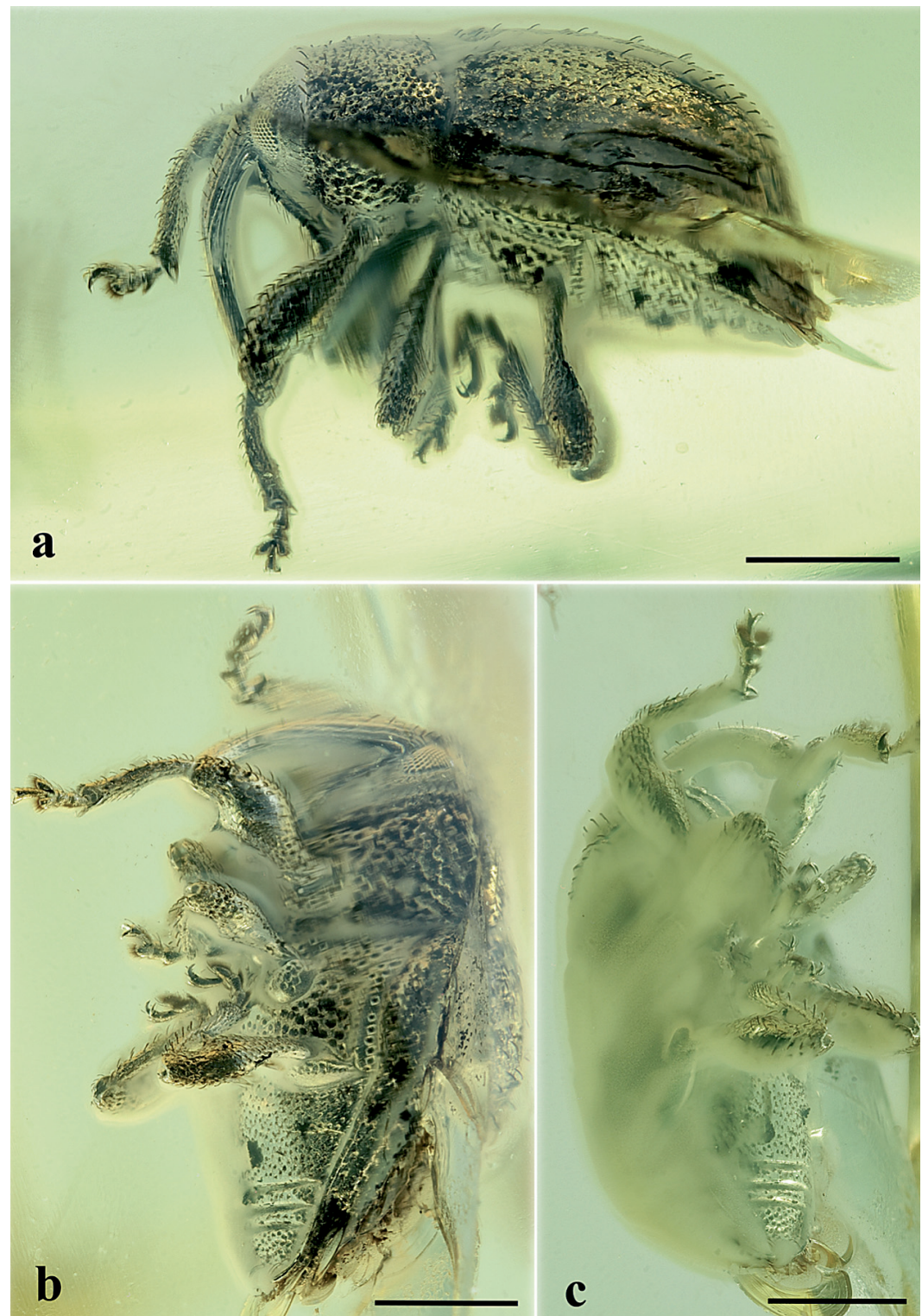

than diameter of one puncture, interspaces rugose and with microreticulation. Prothorax apparently without medial furrow for rostrum reception. Precoxal portion of prothorax elongate, about as long as diameter of procoxa; postcoxal portion of prothorax short, about $0.4 \times$ as long as diameter of procoxa.

Thorax. Elytra elongate-oval, about $2.4 \times$ as long as pronotum, slightly convex, subparallelsided, slightly narrowed posteriad. Elytral punctation moderately dense and large (punctures smaller at elytral apex), punctures arranged in regular rows; distance between punctures in rows about $1.0-1.5 \times$ as long as diameter of one puncture; interstriae slightly convex, with microreticulation, distinctly wider than rows, distance between rows about $2.0-3.0 \times$ as long as diameter of one puncture; row 9 short, fused with row 10 at level of metacoxa. Humeri prominent. Mesoventrite with moderately sparse and small punctation. Metaventrite convex, covered with dense and large punctures, distance between punctures distinctly shorter than diameter of one puncture, with microreticulation. Metepisternum 


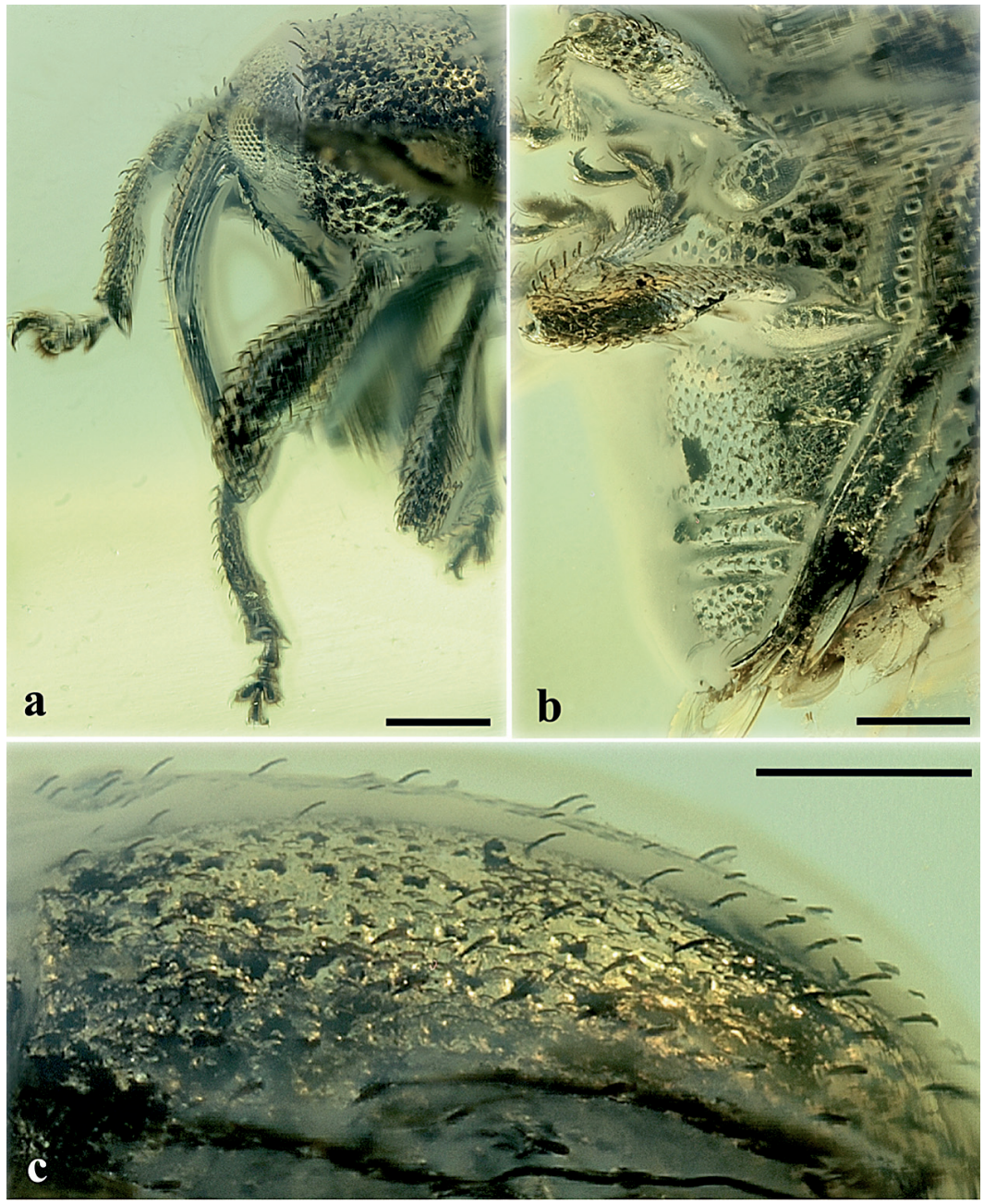

Fig. 2. Dorytomus groehni sp. n., holotype. - a. Forebody in left lateral view. - b. Details of metathorax and abdomen in ventro-lateral view. - c. Disc of left elytron in lateral view. Scale bars 0.5 $\mathrm{mm}$.

elongate, narrow, about $6.5 \times$ as long as wide medially, slightly widened posteriad; with smaller and sparser punctures than metaventrite, distance between punctures about $0.5-1.5 \times$ diameter of one puncture, with microreticulation; with inner lateral margin almost straight and outer lateral margin concave.

Abdomen. With five visible ventrites, slightly convex; punctation small and dense, distance between punctures about 1.5-3.0 $\times$ diameter of one puncture; with microreticulation; ventrite 5 with distinctly denser and deeper punctures (distance between punctures shorter than diameter of one puncture), with posterolateral impressions, with few short erect anal setae apically; ventrites 3 and 4 short, equal in length, ventrite 3 about $0.3 \times$ as long as ventrite 2 . Sutures almost straight; suture between ventrites 1 and 2 weak laterally, obsolete medially; sutures between ventrites $2-5$ deep and sharp. Relative length ratios of ventrites 1-5 equal to 15-14-5-5-12 (medially).

Legs. Moderately long and robust; with fine, dense punctures, covered with sparse, semierect setae; femora slightly shorter than tibiae; forelegs distinctly longer than middle and hind legs. Procoxae rounded, slightly projecting, situated close to prothorax base; mesocoxae almost hemispherical, narrowly separated; metacoxae oval, transverse, distinctly separated. Femora swollen almost medially, not clavate, with sharp teeth ventrally; profemora $2.8 \times$ as long as wide medially, metafemora $3.6 \times$ as long as wide medially; metafemora not reaching abdominal apex. Tibiae elongate, not crenulate on inner margin, with 
uncus and comb of short erect setae apically, without mucro, slightly curved; protibia about $7.7 \times$ as long as wide medially. Tarsi elongate, tarsomere 1 elongate, tarsomere 2 transverse, shorter than tarsomere 1, slightly dilated apically, tarsomere 3 deeply bilobed, transverse, strongly dilated apically, tarsomere 5 narrow, slightly dilated apically, curved, tarsomeres 1-3 densely pubescent ventrally; protarsomere 1 about $1.5 \times$ as long as wide apically, protarsomere 2 about $0.7 \times$ as long as wide apically, about $0.5 \times$ as long as protarsomere 1 , protarsomere 3 about $2.2 \times$ as wide as long, protarsomere 5 about $1.2 \times$ as long as protarsomere 1. Claws free, simple (without teeth basally).

Measurements (lengths). Body (without rostrum) $3.4 \mathrm{~mm}$, rostrum about $1.2 \mathrm{~mm}$; head 0.3 $\mathrm{mm}$; pronotum $0.9 \mathrm{~mm}$; elytra $2.2 \mathrm{~mm}$.

Etymology. The species is named in honor of Carsten Gröhn (Glinde, Germany) who provided us the species for the analysis.

Remarks. The antennal scrobe is directed to the eye. The precoxal portion of the prothorax is elongated, metafemora do not reach the apex of the abdomen, the flagellum is 7-segmented, the claws are simple and the tibiae have uncus and the sutures are straight between the abdominal ventrites. These caracteristics show that this species belongs to the tribe Ellescini. Femora have teeth and ventrite 5 has anal setae confirming the assignment of the specimen to the subtribe Dorytomina. The new species belongs to the genus Dorytomus based on the protibiae not being crenulate on the inner margin.

\section{Discussion}

The genus Dorytomus includes 83 species distributed in predominantly temperate latitudes of the Holarctic (O'Brien 1970, Anderson 2002, Alonso-Zarazaga et al. 2017). Two fossil species were described from the Baltic amber (Legalov 2016a, b). Three species possibly belonging to this genus were described from the terminal Eocene of Florissant (Legalov 2015). The species of this genus are associated with the family Salicaceae, especially Salix L. and Populus L. (Dieckmann 1986), which are known in Baltic amber (Weitschat \& Wichard 2002, Sadowski
2017). It can be assumed that D. groehni sp. n. also developed on Populus which was known in Europe from the Upper Eocene (Collinson 1992).

Acknowledgements. The authors are sincerely grateful to Carsten Gröhn (Glinde, Germany) for the loan of the interesting fossil material and to Jonas Damzen (Vilnius, Lithuania) for permission to use his photographs. We thank two anonymous reviewers for valuable suggestions that improved the manuscript. The study was partially supported by the Russian Foundation for Basic Research, projects no. 18-04-00243-a and 19-04-00465-a and the Federal Fundamental Scientific Research Program for 20132020, project no. AAAA-A16-116121410121-7.

\section{References}

Alonso-Zarazaga, M. A., Barrios, H., Borovec, R., Bouchard, P., Caldara, R., Colonnelli, E., Gültekin, L., Hlavá, P., Korotyaev, B., Lyal, C. H. C., Machado, A., Meregalli, M., Pierotti, H., Ren, L., Sánchez-Ruiz, M., Sforzi, A., Silfverberg, H., Skuhrovec, J., Trýzna, M., Velázquez de Castro, A. J. \& Yunakov, N. N. 2017: Cooperative catalogue of Palaearctic Coleoptera Curculionoidea. - Monografías electrónicas 8: 1-729.

Anderson, R. S. 2002: Curculionidae Latreille 1802: 722 815. — In: Arnett, R. H. Jr. $\dagger$, Thomas, M. C., Skelley, P. E. \& Frank, J. H. (eds.) American beetles, vol 2, Polyphaga: Scarabaeoidea through Curculionoidea. CRC Press, Boca Raton-London-New York-Washington. $x i v+861 \mathrm{pp}$.

Collinson, M. E. 1992: The early fossil history of Salicaceae: a brief review. - Proceedings of the Royal Society of Edinburgh 98B: 155-167. doi: https://doi.org/ $10.1017 / \mathrm{S} 0269727000007521$

Dieckmann L. 1986: Beiträge zur Insektenfauna der DDR: Coleoptera - Curculionidae (Erirhininae). — Beiträge zur Entomologie 36(1): 119-181. [In German.]

Förster, B. 1891: Die Insekten des "Plattigen Steinmergels" von Brunstatt. Mit secht Tafeln im Lichtdruck Abhandlungen der Geologischen Specialkarte von Elsass-Lotheringen 3(5): 333-594 + pls. XI-XVI. [In German.]

Hustache, A. 1942: Un curculionide de l'ambre de la Baltique. - Bulletin Mensuel de la Société Linnéenne de Lyon 11: 108-109. [In French.] doi: https://doi.org/ 10.3406/linly. 1942.9675

Kuska, A. 1992: Three new species of beetles (Coleoptera: Cantharidae, Anobiidae, Curculionidae) from the Baltic amber. - Annals of the Upper Silesian Museum in Bytom - Entomology 3: 107-113.

Kuska, A. 1996: New beetle species (Coleoptera, Cantharidae, Curculionidae) from the Baltic amber. - Prace Muzeum Ziemi 44: 13-23.

Legalov, A. A. 2012: New Curculionoid beetles (Coleoptera: Curculionoidea) from the Baltic amber. - Paleontological Journal 46(3): 262-272. doi: https:// doi.org/10.1134/S0031030112030094 
Legalov, A. A. 2013: New and little known weevils (Coleoptera: Curculionoidea) from the Paleogene and Neogene. - Historical Biology 25(1): 59-80. doi: https://doi.org/10.1080/08912963.2012.692681

Legalov, A. A. 2015: Fossil Mesozoic and Cenozoic weevils (Coleoptera, Obrienioidea, Curculionoidea). Paleontological Journal 49(13): 1442-1513.

Legalov, A. A. 2016a: Two new genera and four new species of fossil weevils (Coleoptera: Curculionoidea) in Baltic amber. - Entomologica Fennica 27(2): 57-69.

Legalov, A. A. 2016b: New weevils (Curculionidae) in Baltic amber. — Paleontological Journal 50(9): 970985. doi: https://doi.org/10.1134/S0031030116090 057

Legalov, A. A. \& Bukejs A. 2015: A new species of the genus Archaeocallirhopalus (Coleoptera: Curculionidae) in Baltic amber. - Entomologica Fennica 26(1): 25-29.

Legalov, A. A. \& Bukejs, A. 2018a: A new genus of the tribe Ceutorhynchini (Coleoptera: Curculionidae) in Baltic amber. - Entomologica Fennica 29(4): 185190.

Legalov, A. A. \& Bukejs, A. 2018b: New findings of weevils (Coleoptera, Curculionioidea) in Baltic amber. Baltic Journal of Coleopterology 18(2): 179-183.

Motschulsky, V. 1857: Voyages. Lettres de M. de Motschulsky à M. Ménétriés. No 4. - Études Entomologiques 5: 21-38. [In French.]

O'Brien, C. W. 1970: A taxonomic revision of the genus Dorytomus in North America (Coleoptera: Curculionidae). - University of California Publications in Entomology 60: 1-80. doi: https://doi.org/10.1093/ aesa/63.1.255

Rheinheimer, J. 2007: Neue fossile Rüsselkäfer (Coleoptera: Curculionidae) aus dem Eozän des Baltischen Bernsteins und der Grube Messel bei Darmstadt. -
Stuttgarter Beiträge zur Naturkunde, Serie B (Geologie und Paläontologie), Nr. 365 1-24. Staatliches Museum für Naturkunde. [In German.]

Sadowski, E.-M. 2017: Towards a new picture of the "Baltic amber forest" - flora, habitat types, and palaeoecology. PhD thesis. - Georg-August University Göttingen. 323 pp. http://hdl.handle.net/11858/00-17350000-0023-3FA3-8.

Sadowski, E.-M., Schmidt, A. R., Kunzmann, L., Gröhn, C. \& Seyfullah, L. J. 2016: Sciadopitys cladodes from Eocene Baltic amber. - Botanical Journal of the Linnean Society 180: 258-268. doi: https://doi.org/ 10.1111/boj.12365

Schubert, K. 1961: Neue Untersuchungen über Bau und Leben der Bernsteinkiefern (Pinus succinifera (Conw.) emend.). - Beihefte Geologischen Jahrbuch 45: 1-149.

Ulke, T. 1947: A new genus and species of Curculionidae (Coleoptera) in Baltic amber. - Notulae Naturae. Philadelphia 193: 1-5.

Voss, E. 1953: Einige Rhynchophoren der Bernsteinfauna (Col.). - Mitteilungen des geologischen Staatsinstitutes von Hamburg 22: 119-140. [In German.]

Voss, E. 1972: Einige Rüsselkäfer der Tertiärzeit aus Baltischem Bernstein (Coleoptera, Curculionoidea). Steenstrupia 2: 167-181. [In German.]

Weitschat, W. \& Wichard, W. 2002: Atlas of plants and animals in Baltic amber. - München, Pfeil. 256 pp.

Yunakov, N. N. \& Kirejtshuk, A. G. 2011: New genus and species of broad-nosed weevils from Baltic amber and notes on fossils of the subfamily Entiminae (Coleoptera, Curculionidae). - ZooKeys 160: 73-96. doi: https://doi.org/10.3897/zookeys.160.2108

Zherikhin, V. V. 1971: On weevils (Insecta, Coleoptera) from the Baltic Amber. - Trudy Paleontologicheskogo Instituta, Moscow 130: 197-209. [In Russian.] 